\title{
ENHANCEMENT OF ROCK PHOSPHATE APPLICABILTY BY COMPOST AND PHOSPHATE DISSOLVING BACTERIA AND ITS EFFECT ON QUALITY AND PRODUCTIVITY OF CANOLA PLANT GROWN IN SANDY SOILS
}

\author{
Y. M. El-Edfawy and M. M. Harvey \\ Soils, Water and Environment Research Institute, Agric. Res. Center, Giza, Egypt. \\ E-mails: yassereledfawy@yahoo.com moheyharvey11@yahoo.com
}

Received: May. 9, 2018

Accepted: Jun. 9 , 2018

\begin{abstract}
Two field experiments were conducted during the two early winter seasons of 2014/2015 and 2015/2016 at Ismailia Agricultural Research Station, Agricultural Research Center (ARC), Ismailia Governorate, Egypt. Aim was to evaluate enhancement of applicability of rock phosphate by addition of compost and inoculation with phosphate dissolving bacteria and its effect on quality and productivity of canola plant. The experiment included 3 factors as follows: (1) three rates of rock phosphate i.e. 0 (RP $), 250 \mathrm{~kg} \mathrm{ha}^{-1}\left(R P_{1}\right)$ and $500 \mathrm{~kg} \mathrm{ha}^{-1}\left(R P_{2}\right.$, (2) two treatments of compost: without application $C_{0}$ and $24 \mathrm{Mg} \mathrm{ha}^{-1}\left(C_{1}\right)$ and (3) two P-dissolving bacteria (PDB): none (PDB ${ }_{0}$ ) and inoculation $\left(P D B_{1}\right)$. The highest values of plant growth characters, yield and its component, seed quality, nutrient content and their uptake of canola plant were obtained under treatment of $R P_{2}+C_{1}+P D B_{1}$. It could be concluded that, the combined use of rock phosphate at rate of $500 \mathrm{~kg} \mathrm{ha}^{-1}$ and compost manure at rate of $24 \mathrm{Mg} \mathrm{ha}^{-1}$ plus seed inoculation with PDB was more economical due to reduce and costs of the used fertilizers with access to results would be an appropriate substitute for chemical phosphorous fertilizer in sustainable agriculture system.
\end{abstract}

Key words: Canola plant, Organic composts, Phosphate dissolving bacteria, Rock phosphate and Sandy soil,

\section{INTRODUCTION}

Canola plants (Brassica napus L.) are an important oil crop that ranks only behind soybean and palm oil in global production. In Egypt canola has a bright future to contribute in reducing oil deficiency gaps between production and consumption of edible oil. Canola plant is considered one of the new crops with high water use efficiency or high drought tolerance that can be used for oil seed production in the arid regions of the world (Leilah and Al-Khateeb, 2003). In Egypt, more desert areas of sandy calcareous soils have to be put under cultivation. Thus, growing canola in these soils could be successful, because these soils are less fertile and could produce relatively high economic yield with low level inputs mainly NPK fertilizers as mixed with organic manure (Ahmed et al.; 2005).

Phosphorus $(P)$ is a major key nutrient for plants and affects several characteristics of plant growth. Though $P$, both in organic and inorganic forms is abundant, but due to its ability to form complexes with other soil constituents, it is not easily available for uptake by the plants (Khan et al., 2009). Therefore, frequent application of important amounts of chemical fertilizers containing soluble forms of $P$ is needed to achieve maximum plant productivity (Gyaneshwar et al., 2002). Production of chemical fertilizers is based on chemical processing of insoluble mineral phosphate (high-grade ore) by treating them with sulfuric acid at high 
temperature. Thus, the process is environmentally undesirable and a costly affair (Vassilev et al., 2006). Excessive and indiscriminate application of chemical fertilizers show adverse impact on the soils in that soil micro flora and fauna (which impart natural properties to the soils) are destroyed thereby resulting into decreased agricultural production after years of application. Rock phosphate (RP) is a natural phosphorus source which can be an alternative to chemical fertilizers; unfortunately, it is soluble in acidic soils only and is not applicable in alkaline soils. Canola crop requires a suitable amount of rock phosphate (RP) as phosphate fertilizers, for better crop production. The insoluble $P$ content of RP may be converted to the soluble form by chemical acidulation and biological means.

Microbial solubilization of rock phosphate is gaining importance as microbes release organic acids to solubilize rock phosphate. Phosphate solubilizing bacteria having ability to solubilize rock phosphate (Yadav et al., 2014). Phosphate solubilization by bacteria is more efficient than fungi and bacterial processes are much easier for industrial application. The microbial strain such as P-dissolving bacteria is one of the most important agents to sustain $P$ availability in the treated soil. These strain agents are the primary substances controlling the enhanced plant growth, absorption nutrients and photosynthesis process (Makovacki and Milic, 2001). Moreover, seed inoculation with bio-fertilizer is economically important as it resulted in reducing the needs of $N$ and $P$ fertilizers and improving the crop yield. (Romano, et al 2017) found that bio-fertilization improved plant growth characters and seed yield of sunflower plants.

The application of compost to soil can improve the soil quality, supply nutrients to plants and soil microbes, and reduce environmental pollution (Yang, 2003). Organic composts contained macro nutrients, trace elements, organic substances like amino acids and plant growth regulators such as auxin, cytokinin. Organic composts are known to enhance seed germination and plant growth (Thirumaran et al.; 2009). They have been also shown to increase crop yield, improve growth and induce resistance to frost, fungal and insect attack and increase nutrient uptake from the soil. Further organic matter (that matrixed rock phosphate particles) complexes soil cations, thereby preventing fixation of $P$. Thus compost is an ideal medium to increase the efficacy of rock phosphate and appears to be the best medium for direct application of rock phosphate, compost charged by rock phosphate along with phosphate solubilizing bacteria can be used as an efficient $P$ fertilizer.

The current work aims to evaluate the applying different rates of rock phosphate and addition of compost on canola plant (Brassica napus L.) inoculated with P-dissolving bacteria (PDB) grown on sandy soil in order to develop a cost effective, eco-friendly and sustainable system where the supply of phosphorus to plants can be ensured.

\section{MATERIALS AND METHODS \\ Site description}

the field experiments were conducted along two winter successive seasons of 2014/2015 and 2015/2016 at Ismailia Agricultural Experimental Station, Agricultural Research Center (ARC), Egypt located between Latitude $29^{\circ} 21^{\prime} 48^{\prime \prime} \mathrm{N}$ and Longitude $30^{\circ} 44^{\prime} 45^{\prime \prime} \mathrm{E}$. Main properties of soil, and chemical composition of both compost and rock phosphate were carried out according to Klute et al.; (1986) and the obtained data are recorded in Tables 1,2 and 3. Available $N, P$ and $K$ in soil were 
extracted by $1 \% \mathrm{~K}_{2} \mathrm{SO}_{4}, 0.5 \mathrm{M}$ solution sodium bicarbonate and $1 \mathrm{~N}$ ammonium acetate respectively, and were determined according to Jackson, (1973) and determined using Atomic Absorption Spectrophotometer.

\section{Experimental design}

The experimental design was a randomized complete block including 16 treatments with three replicates. The experiment included 3 factors as follows: (1) three rates of rock phosphate i.e. 0 $\left(\mathrm{RP}_{0}\right), 250 \mathrm{~kg} \mathrm{ha}^{-1}\left(\mathrm{RP}_{1}\right)$ and $500 \mathrm{~kg} \mathrm{ha}^{-1}$ $\left(\mathrm{RP}_{2}, \quad\right.$ (2) two application rates of compost: without application " $\mathrm{C}_{0}$ " and 24 $\mathrm{Mg} \mathrm{ha}^{-1}$ " $\mathrm{C}_{1}$ " and (3) two P-dissolving bacteria (Bacillus megaterium var.) PDB: none "PDB ${ }_{0}$ " and inoculation "PDB ${ }_{1}$ ". All treatments were replicated three times. The experimental unit area was $10.5 \mathrm{~m}^{2}$ with dimensions $3 \times 3.5 \mathrm{~m}$, each plot included 4 ridges $(3.5 \mathrm{~m}$ in length and 30 cm in width).

\section{Crop management}

Rock phosphate and applied compost were incorporated into the soil 21 days before sowing. Canola seeds (Brassica napus $L$.) were inoculated with $P$ dissolving bacteria (PDB) on the same day of sowing, where phosphate absorbed on peat-moss power as carrier and registered to bio-fertilizers unit, Ministry of Agric., Egypt from which it was obtained. Hill spacing was $10 \mathrm{~cm}$ within the row. Seeds were sown 3-5 seeds on each hill on the second half of November. Normal Irrigation water was used immediately after sowing, then every one week interval according to agronomic practices in the district. Thinning was carried out at $\mathbf{1 5}$ days after sowing to secure two plants per hill on both sides of the ridge. Nitrogen fertilizer was added as ammonium nitrate at rate of $0.34 \mathrm{~kg} \mathrm{~N} \mathrm{~kg}^{-1}$ in two equal doses, the first dose was carried out after thinning and the second one was carried out at flowering stage. Also potassium fertilizer was added in the form of potassium sulphate at rate of $0.398 \mathrm{~kg} \mathrm{~K} \mathrm{~kg}^{-1}$ in two equal doses. First dose was added after one month of planting and the second was carried out after 21 days of the first dose.

Table 1. Main characteristics of the studied soil.

\begin{tabular}{|c|c|c|c|c|c|c|c|c|c|c|}
\hline \multicolumn{4}{|c|}{ (\%) Particle size distribution } & \multirow{2}{*}{$\begin{array}{l}\text { Texture } \\
\text { class }\end{array}$} & \multirow{2}{*}{$\begin{array}{c}\mathrm{CaCO}_{3} \\
(\mathrm{~g} \mathrm{kg-1})\end{array}$} & \multirow{2}{*}{$\begin{array}{c}O . M \\
(g \mathrm{~kg}-1)\end{array}$} & \multirow[b]{2}{*}{ pH } & \multirow[b]{2}{*}{ EC } & \multirow{2}{*}{$\begin{array}{l}\text { SP } \\
\text { (\%) }\end{array}$} & \multirow{2}{*}{$\begin{array}{c}\text { CEC } \\
\text { (cmolc } \\
\mathrm{kg}^{-1} \text { soil) }\end{array}$} \\
\hline $\begin{array}{l}\text { Coarse } \\
\text { sand }\end{array}$ & $\begin{array}{l}\text { Fine } \\
\text { sand }\end{array}$ & Silt & Clay & & & & & & & \\
\hline 78.01 & 9.6 & 5.61 & 0.10 & andy & 2.1 & 3.6 & 7.43 & 0.93 & 14.4 & 3.16 \\
\hline \multicolumn{4}{|c|}{ Soil cations (mmolc $\mathrm{L}^{-1}$ ) } & \multicolumn{4}{|c|}{ Soil anions $\left(\mathrm{mmolc} \mathrm{L}^{-1}\right)$} & \multicolumn{3}{|c|}{$\begin{array}{c}\text { Available macronutrien } \\
\left(\mathrm{mg} \mathrm{kg}^{-1}\right)\end{array}$} \\
\hline $\mathrm{Ca}^{+2}$ & $\mathrm{Mg}^{+2}$ & $\mathrm{Na}^{+}$ & $\mathrm{K}^{+}$ & $\mathrm{CO}^{-2}$ & $\mathrm{HCO}_{3}^{-}$ & $\mathrm{Cl}^{-}$ & $\mathrm{SO}^{-2}$ & $\mathbf{N}$ & $\mathbf{P}$ & $\mathrm{K}$ \\
\hline 3.1 & 3.8 & 2.25 & 0.15 & 0 & 4.68 & 3.89 & 0.73 & 16.53 & 6.33 & 29.31 \\
\hline
\end{tabular}

pH of $1: 2.5$ soil : water suspension. EC: of soil past extract

Table 2. Main characteristics of applied compost.

\begin{tabular}{|c|c|c|c|c|c|c|c|c|}
\hline $\begin{array}{c}\mathrm{O} . \mathrm{M} \\
\left(\mathrm{g} \mathrm{kg}^{-1}\right)\end{array}$ & $\begin{array}{c}\text { Total C } \\
\left(\mathrm{g} \mathrm{kg}^{-1}\right)\end{array}$ & $\begin{array}{c}\text { Total N } \\
(\mathbf{g ~ k g - 1 )}\end{array}$ & $\begin{array}{c}\text { Total P } \\
(\mathbf{g ~ k g - 1 )}\end{array}$ & $\begin{array}{c}\text { Total K } \\
(\mathbf{g ~ k g - 1 )}\end{array}$ & $\begin{array}{c}\mathrm{C} / \mathrm{N} \\
\text { ratio }\end{array}$ & $\begin{array}{c}\mathrm{EC} \\
\left(\mathrm{dSm}^{-1}\right)\end{array}$ & $\mathbf{p H}$ & $\begin{array}{c}\text { Bulk } \\
\text { density } \\
\left(\mathrm{Mg} \mathrm{m}^{-3}\right)\end{array}$ \\
\hline 358.7 & 252.6 & 13.4 & 8.5 & 16.8 & 18.9 & 2.3 & 7.3 & 0.83 \\
\hline
\end{tabular}

pH of $1: 5$ compost : water suspension. EC: of 1: 10 compost : water extract.

Table 3. Main characteristics of applied rock phosphate. 


\begin{tabular}{|l|c|c|c|c|c|c|c|}
\hline Character & $\mathrm{P}$ & $\mathrm{Ca} \mathrm{O}$ & $\mathrm{Fe}_{2} \mathrm{O}_{3}$ & $\mathrm{SiO}_{2}$ & $\mathrm{Mg} \mathrm{O}$ & $\mathrm{SO}_{4}$ & $\mathrm{CaCO}_{3}$ \\
\hline Value (\%) & 12.85 & 44.2 & 1.4 & 4.22 & 2.15 & 1.06 & 11.91 \\
\hline
\end{tabular}

Plant analysis

At harvest plant samples of both seeds and straw were collected for determination of the growth parameter, yield and its components and uptake of macro nutrients. Nitrogen was determined with a micro-Kjeldahl (Chapman and Pratt, 1961). Phosphorus was determined calorimetrically, according to Watanabe and Olsen, (1965). Potassium was determined using a Flame photometer, according to Jackson, (1973). Phosphorous contents in plant were determined by using a standard turbidity method according to (Issam and Sayegh, 2007). Crude protein was calculated by multiplying total seed $\mathrm{N}$ content by 6.25 (Deyoe and Shellenberger, 1965). The oil content of canola seeds was determined by using a soxchlet according to A.O.A.C. (1990) while, oil yield estimated by multiplying seed yield ( $\mathrm{kg} \mathrm{ha}^{-1}$ ) by oil content. All collected data were statistically analyzed according to Sedecor and Cochron (1980), to define the values of L.S.D.

\section{RESULTS AND DISCUSSION Growth characters}

Data in Table 4 show that plant growth characters of canola plants are significantly increased due to the all treatments. With respect to the effect of rock phosphate application of the growth of canola plant, the rock phosphate causes gradually increased with increasing the application rate. Increasing percentages for $\mathbf{R P}_{2}$ treatments were $71.47,57.22$ and $126.70 \%$ for plant height, dry weight and number of branch/plant, respectively over control treatment. Such effect may be due to that phosphorous encourage the growth of root system and enhance the photosynthesis, carbohydrates metabolites synthesized by plants and consequently increase plant growth characters. These results are in same line with those obtained by Abo-Baker and Hassan (2017)

Table 4. Growth characters of canola plant as affected by rock phosphate, compost and phosphate dissolving bacteria treatments.

\begin{tabular}{|c|c|c|c|c|c|c|c|c|c|c|}
\hline \multirow{3}{*}{$\mathbf{R P}$} & \multirow{3}{*}{ ompost } & \multicolumn{9}{|c|}{ PDB treatments } \\
\hline & & $\mathrm{PDB}_{0}$ & $\mathrm{PDB}_{1}$ & Mean & $\mathrm{PDB}_{0}$ & $\mathrm{PDB}_{1}$ & Mean & $\mathrm{PDB}_{0}$ & $\mathrm{PDB}_{1}$ & Mean \\
\hline & & \multicolumn{3}{|c|}{ Plant height $(\mathbf{c m})$} & \multicolumn{3}{|c|}{ Dry weight plant $^{-1}(\mathrm{~g})$} & \multicolumn{3}{|c|}{ No. of branches plant ${ }^{-1}$} \\
\hline \multirow{2}{*}{ RPO } & $\mathrm{C}_{0}$ & 78.13 & 81.35 & 79.74 & 70.26 & 73.68 & 71.97 & 5.29 & 6.47 & 5.88 \\
\hline & $\mathrm{C}_{1}$ & 83.74 & 87.56 & 85.65 & 81.73 & 86.45 & 84.09 & 7.18 & 9.36 & 8.27 \\
\hline \multicolumn{2}{|r|}{ Mean } & 80.94 & 84.46 & 82.70 & 76.00 & 80.07 & \begin{tabular}{|l|}
78.03 \\
\end{tabular} & 6.24 & 7.92 & 7.08 \\
\hline \multirow{2}{*}{ RP1 } & $\mathrm{C}_{0}$ & 95.22 & 98.84 & 97.03 & 90.37 & 98.98 & & 10.35 & 11.26 & 10.81 \\
\hline & $C_{1}$ & 112.86 & 119 & & & & & & 46 & 5 \\
\hline \multicolumn{2}{|r|}{ Mean } & 104.04 & 109.13 & 106 & 95 & & 10 & & 86 & .23 \\
\hline \multirow{2}{*}{ RP2 } & $\mathrm{C}_{0}$ & 131.29 & 140.97 & 136.13 & 113 & 120.81 & 117.12 & 15 & 15.81 & 15.47 \\
\hline & $\mathrm{C}_{1}$ & 143.44 & 151.55 & 147.50 & 125.32 & 131.15 & 128.24 & 16 & 16.94 & 16.64 \\
\hline \multicolumn{2}{|r|}{ Mean } & 137.37 & 146.26 & 141.81 & $11 \mathrm{~s}$ & 12 & 122.68 & 15 & 16.38 & 16.05 \\
\hline \multicolumn{2}{|c|}{ Grand mean } & 107.45 & 113.28 & 110.36 & 97.06 & 103.64 & 35 & 1 & 12.38 & 11.78 \\
\hline \multicolumn{11}{|c|}{ Means of compost } \\
\hline & $\mathrm{C}_{0}$ & 101.55 & 107.05 & 104.30 & 91.35 & 97.82 & 94.59 & & 11.18 & 10.72 \\
\hline & $C_{1}$ & 113.35 & 119.51 & 116.43 & 102.77 & 109.45 & 106.11 & 12.11 & 13.59 & 12.85 \\
\hline \multicolumn{2}{|c|}{$\operatorname{LSD}_{0.05}$} & \multicolumn{3}{|c|}{$\begin{array}{c}\mathrm{RP}=\mathrm{ns} \mathrm{C}=10.13 \text { PDB=1.98 } \\
\mathrm{RPxC}=34.46 \text { RPxPDB }=22.73 \\
\text { CxPDB }=n s\end{array}$} & \multicolumn{3}{|c|}{$\begin{array}{l}R P=25.55 \quad C=10.79 \text { PDB }=4.85 \\
R P x C=33.77 \text { RPXPDB }=24.64 \\
\text { CxPDB }=\text { ns RxCXPDB=27.11 } \\
\end{array}$} & \multicolumn{3}{|c|}{$\begin{array}{l}\mathrm{RP}=n s \mathrm{C}=1.76 \text { PDB }=0.98 \\
\mathrm{RPXC}=5.77 \quad \mathrm{RPxPDB}=3.88 \\
\mathrm{CxPDB}=\mathrm{ns} \text { RxCXPDB=6.89 }\end{array}$} \\
\hline
\end{tabular}


\begin{tabular}{|l|c|c|c|}
\hline & RxCXPDB=18.57 & & \\
\hline
\end{tabular}

$\mathrm{RP}_{0}, \mathrm{RP}_{1}$ and $\mathrm{RP}_{2}: 0,250$ and $500 \mathrm{~kg} \mathrm{ha}^{-1}$ of rock phosphate, $\mathrm{C}_{0}$ and $\mathrm{C}_{1}: 0$ and $24 \mathrm{Mg} \mathrm{ha}^{-1}$ of compost $\mathrm{PDB}_{0}$ and $\mathrm{PDB}_{1}$ : none and inoculation with phosphate dissolving bacteria, n.s non-significant at the $5 \%$ levels of probability at L.S.D test.

Results also showed that application of compost manure had a significant increase effect on growth characters of canola plant (table 4). Increments due to $C_{1}$ were $11.62,12.17$ and $19.86 \%$ for plant height, dry weight and number of branch/plant, respectively as compared with untreated plants (control). Same results were obtained by Awad et al. (2009).

Data resulted in Table (4) revealed that inoculation of canola seeds with phosphorous dissolving bacteria (PDB) significantly increases all of investigated plant growth characters. The corresponding relative increments due to $\mathrm{PDB}_{1}$ were 5.42, 6.77 and $10.73 \%$ for plant height, dry weight and number of branch/plant, respectively as compared with un-inoculated plants. These increases may be due to stimulation plant hormones production such as auxins, cytokines, gibberellins and also some volatile compounds. These results in accordance with those obtained by Abo-Baker and Hassan (2017)

Regarding to the interaction effect of the studied three factors, data in Table (4) reveal that different levels of RP combined with PDB inoculation led to a marked increase in plant growth characters. Percentages of $\mathbf{R P}_{2}+\mathbf{P D B}_{1}$ treatment were $80.70,65.76$ and $162.5 \%$ for plant height, dry weight and number of branch/plant, respectively as compared with $\mathbf{R P}_{0} \times \mathbf{P D B}_{0}$. Results also indicate that different rates of RP with compost application resulted significant increase in the studied plant growth characters as compared with RPO + $\mathrm{CO}$. These results are in agreement with those obtained by Awad et al. (2009) and El-Edfawy (2012). With respect to the interaction effect between RP application rates as combined with compost manure plus PDB seed inoculation, results indicated that the combined treatment of $\mathrm{RP}_{2}+\mathrm{C}_{1}+\mathrm{PDB}_{1}$ proved to be even superior among other treatments in terms of plant growth characters of canola plant which produced 94.0, 86.6 and $220.23 \%$ for plant height, dry weight and number of branch/plant, respectively as compared with unfertilized treatment. These increments might be due to the organic compounds which resulted during the decomposition of organic matter that can help to dissolution the fixed from of $P$ in rock phosphate and increase the uptake of phosphorous by plant and also organic matter provide substrate for microbial growth which enhance plant growth characters. These results are in harmony with obtained by Abd El-Moneim et al. (2015).

\section{Yield and yield component}

Results in Table (5) indicated that, the application rates of RP gave markedly increase in all yield characters under study. The $\mathbf{R P}_{\mathbf{2}}$ treatment were enhanced No. of pods/plant by $75.12 \%, 1000$ seed weight by $12.33 \%$, seed yield by $42.18 \%$ and straw yield by $\mathbf{3 2 . 2 1 \%}$ as compared with RPO. Same results were obtained by Zapta and Roy (2004) and Abo-Baker and Hassan (2017).

As regard to the main effect of PDB inoculation on yield and yield components of canola plant, the obtained results in Table 5 showed that seed inoculation with PDB led to significant increase in all yield characters the percentages were 2.94, 1.73, 1.46 and $1.16 \%$ for No. of pods/plant, 1000 seed weight, seed yield and straw yield, 
respectively. These results are in the same line with those obtained by AboBaker and Hassan (2017). characters of canola plant as compared to untreated plants (Table 5) El-Edfawy (2012) obtained the same results.

Data also of this study, clear that using of compost manure at rate of $24 \mathrm{Mg}$ $\mathrm{ha}^{-1}$ had a positive effect on the yield

Table 5. Yield and its component of canola plant as affected by rock phosphate application, compost manure and phosphate dissolving bacteria treatments.

\begin{tabular}{|c|c|c|c|c|c|c|c|c|c|c|}
\hline \multirow{3}{*}{$\mathbf{R P}$} & \multirow{3}{*}{ Compost } & \multicolumn{9}{|c|}{ PDB treatments } \\
\hline & & $\mathrm{PDB}_{0}$ & $\mathrm{PDB}_{1}$ & Mean & $\mathrm{PDB}_{0}$ & $\mathrm{PDB}_{1}$ & Mean & $\mathrm{PDB}_{0}$ & $\mathrm{PDB}_{1}$ & Mean \\
\hline & & \multicolumn{3}{|c|}{ No. of pods plant ${ }^{-1}$} & \multicolumn{3}{|c|}{1000 seed weight $(g)$} & \multicolumn{3}{|c|}{ Seed yield $\left(\mathrm{kg} \mathrm{ha}^{-1}\right)$} \\
\hline \multirow{2}{*}{$\mathbf{R P}_{0}$} & $\mathrm{C}_{0}$ & 186.86 & 193.17 & 190.02 & 2.13 & 2.16 & 2.15 & 710.33 & 719.21 & 714.77 \\
\hline & $\mathrm{C}_{1}$ & 196.35 & 203.75 & 200.05 & 2.21 & 2.25 & 2.23 & 743.20 & 755.80 & 749.50 \\
\hline \multicolumn{2}{|c|}{ Mean } & 191.61 & 198.46 & 195.03 & 2.17 & 2.21 & 2.19 & 726.77 & 737.51 & 732.14 \\
\hline \multirow{2}{*}{$\mathbf{R P}_{\mathbf{1}}$} & $\mathrm{C}_{0}$ & 253.11 & 261.42 & 257.27 & 2.29 & 2.32 & 2.31 & 851.43 & 868.90 & 860.17 \\
\hline & $\mathrm{C}_{1}$ & 288.74 & 296.35 & 292.55 & 2.35 & 2.39 & 2.37 & 885.12 & 896.31 & 890.72 \\
\hline \multicolumn{2}{|c|}{ Mean } & 270.93 & 278.89 & 274.91 & 2.32 & 2.36 & 2.34 & 868.28 & 882.61 & 875.44 \\
\hline \multirow{2}{*}{$\mathbf{R P}_{2}$} & $\mathrm{C}_{0}$ & 328.25 & 336.82 & 332.54 & 2.41 & 2.45 & 2.43 & 963.20 & 975.04 & 969.12 \\
\hline & $\mathrm{C}_{1}$ & 346.16 & 354.94 & 350.55 & 2.48 & 2.51 & 2.50 & 1105.28 & 1120.30 & 1112.79 \\
\hline \multicolumn{2}{|c|}{ Mean } & 337.21 & 345.88 & 341.54 & 2.45 & 2.48 & 2.46 & 1034.24 & 1047.67 & 1040.96 \\
\hline \multicolumn{2}{|c|}{ Grand mean } & 266.58 & 274.41 & 270.49 & 2.31 & 2.35 & 2.33 & 876.43 & 889.26 & 882.84 \\
\hline \multicolumn{11}{|c|}{ Means of compost } \\
\hline & $\mathrm{C}_{0}$ & 56.07 & 263.80 & 259.94 & 2.28 & 2.31 & 2.29 & 841.65 & 854.38 & 848.02 \\
\hline & $\mathrm{C}_{1}$ & 277.08 & 285.01 & 281.05 & 2.35 & 2.38 & 2.37 & 911.20 & 924.14 & 917.67 \\
\hline \multirow{2}{*}{\multicolumn{2}{|c|}{$\operatorname{LSD}_{0.05}$}} & \multicolumn{3}{|c|}{$\begin{array}{c}\mathrm{RP}=83.56 \mathrm{C}=20.69 \mathrm{PDB}=6.12 \\
\mathrm{RPXC}=\mathrm{ns} \text { RPXPDB=90.45 } \\
\mathrm{CxPDB}=89.67 \text { RxCXPDB=55.79 }\end{array}$} & \multicolumn{3}{|c|}{\begin{tabular}{|c|c|}
$\mathrm{RP}=0.15 \quad \mathrm{C}=0.04 \quad \mathrm{PDB}=0.03$ \\
$\mathrm{RPXC}=0.14 \quad \mathrm{RPPPDB}=0.12$ \\
$\mathrm{CxPDB}=0.07$ RxCXPDB $=0.22$ \\
\end{tabular}} & \multicolumn{3}{|c|}{$\begin{array}{c}\mathrm{RP}=222.64 \mathrm{C}=65.66 \mathrm{PDB}=10.39 \\
\mathrm{RPCC}=255.48 \text { RPXPDB }=97.96 \\
\mathrm{CxPDB}=66.59 \mathrm{RxCXPDB}=98.92\end{array}$} \\
\hline & & \multicolumn{3}{|c|}{ Straw yield $\left(\mathrm{kg} \mathrm{ha}^{-1}\right)$} & \multicolumn{3}{|c|}{ Harvest index (\%) } & \multicolumn{3}{|c|}{ Crop index (\%) } \\
\hline \multirow[t]{2}{*}{$\mathbf{R P}_{0}$} & $\mathrm{C}_{0}$ & 903.41 & 915.90 & 909.66 & 44.02 & 43.99 & 44.00 & 78.63 & 78.52 & 78.58 \\
\hline & $\mathrm{C}_{1}$ & 934.23 & 946.48 & 940.36 & 44.31 & 44.40 & 44.35 & 79.55 & 79.85 & 79.70 \\
\hline \multicolumn{2}{|c|}{ Mean } & 918.82 & 931.19 & 925.01 & 44.16 & 44.19 & 44.18 & 79.09 & 79.19 & 79.14 \\
\hline \multirow[t]{2}{*}{$\mathbf{R} \mathbf{P}_{1}$} & $\mathrm{C}_{0}$ & 1026.81 & 1035.40 & 1031.11 & 45.33 & 45.63 & 45.48 & 82.92 & 83.92 & 83.42 \\
\hline & $\mathrm{C}_{1}$ & 1069.63 & 1082.91 & 1076.27 & 45.28 & 45.29 & 45.28 & 82.75 & 82.77 & 82.76 \\
\hline \multicolumn{2}{|c|}{ Mean } & 1048.22 & 1059.16 & 1053.69 & 45.31 & 45.46 & 45.38 & 82.84 & 83.34 & 83.09 \\
\hline \multirow[t]{2}{*}{$\mathbf{R P}_{2}$} & $\mathrm{C}_{0}$ & 1180.58 & 1196.40 & 1188.49 & 44.93 & 44.90 & 44.92 & 81.59 & 81.50 & 81.54 \\
\hline & $\mathrm{C}_{1}$ & 1251.93 & 1263.10 & 1257.52 & 46.89 & 47.00 & 46.95 & 88.29 & 88.69 & 88.49 \\
\hline \multicolumn{2}{|c|}{ Mean } & 1216.26 & 1229.75 & 1223.00 & 45.91 & 45.95 & 45.93 & 84.94 & 85.10 & 85.02 \\
\hline \multicolumn{2}{|c|}{ Grand mean } & 1061.10 & 1073.37 & 1067.23 & 45.13 & 45.20 & 45.16 & 82.29 & 82.54 & 82.42 \\
\hline & & & & Means & of com & post & & & & \\
\hline & $\sigma_{0}$ & 6.93 & 1049.23 & 1043.08 & 44.76 & 44.84 & 44.80 & 1.04 & 81.31 & 81.18 \\
\hline & $C_{1}$ & 1085.26 & 1097.50 & 1091.38 & 45.49 & 45.56 & 45.53 & 83.53 & 83.77 & 83.65 \\
\hline
\end{tabular}




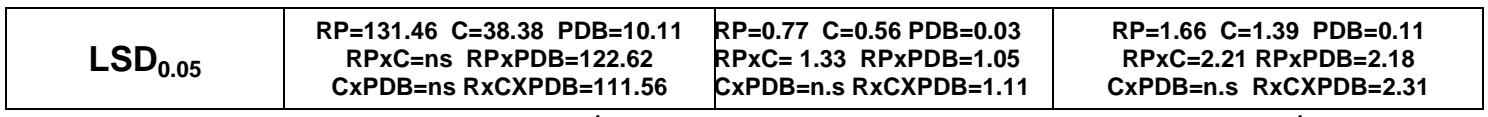

$\mathbf{R P}_{0}, \mathbf{R P}_{1}$ and $\mathbf{R P}_{2}: 0,250$ and $500 \mathrm{~kg} \mathrm{ha}^{-1}$ of rock phosphate, $\mathrm{C}_{0}$ and $\mathrm{C}_{1}: 0$ and $24 \mathrm{Mg} \mathrm{ha}^{-1}$ of compost $\mathrm{PDB}_{0}$ and $\mathrm{PDB}_{1}$ : none and inoculation with phosphate dissolving bacteria, n.s non-significant at the $5 \%$ levels of probability at L.S.D test.

Concerning to the interaction effect of the studied three factors, results in Table (5) indicate that the combined application of $\mathbf{R P}+\mathrm{PDB}$ particularly treatment of $\mathbf{R P}_{2}$ $+\mathrm{PDB}_{1}$ gave significant increase in all yield characters i.e. No. of pods/plant, 1000 seed weight, seed yield, straw yield, harvest index and crop index. These results are in harmony with obtained by Abo-Baker and Hassan (2017). Also the obtained results clear that the combined effect of the $\mathbf{R P}_{2}$ treatment with application of compost manure at rate of $24 \mathrm{Mg} \mathrm{ha}^{-1}$ significantly increased all yield characters at maturity stage of canola plant. The respective increase were $84.48,16.28,55.69$ and $38.24 \%$ for No. of pods/plant, 1000 seed weight, seed yield and straw yield, respectively over control treatment. These results might be due to the compost manure could produce organic acid which lowered $\mathrm{pH}$ nearer plant roots which increased the availability of $\mathbf{P}$ from RP and improved its efficiency that promote growth and yield of canola plant (Awad et al. 2009). Also results in Table (5) reveal that, the highest values were obtained under combined treatment of $\mathbf{R P}_{2}+\mathbf{C}_{1}+\mathbf{P D B}_{1}$ which led to positive and significant increase in all yield characters. These increases were $89.94,17.84,57.72,39.81$, 6.77 and $12.80 \%$ for No. of pods/plant, 1000 seed weight, seed yield straw yield, harvest index and crop index, respectively over control treatment. These increase may be due to compost manure stimulating and increase the activity of PDB that can in turn producing the organic acids that may help acidify and dissolve RP and thus increasing Puptake by plant which ultimately reflected it increased growth and yield for canola plant. (Awad et al. 2009).

\section{Seed quality}

Results in Table (6) reveal that oil and protein contents of canola plant were not responded significantly by the tested treatments. However, the combined treatment of $\mathrm{RP}_{2}+\mathrm{C}_{1}+\mathrm{PDB}_{1}$ led to significant increase in oil and protein content. Increments were 3.38 and $3.54 \%$ for oil and protein content, respectively compared with the control. Also data in the same Table clear that the oil yield of canola plant was affected significantly by all treatments in this study. The greatest value of oil yield in canola seeds was associated with the combined treatment of $\mathrm{RP}_{2}+\mathrm{C}_{1}+\mathrm{PDB}_{1}$ which produced $62.73 \%$ relative to unfertilized plants. This might be due to that $P$ is required for production of high quality of seeds. Since it occurs as co-enzymes involved in energy transfer reactions, energy tapped in photosynthesis in form of adenosine triphosphate (ATP) and nicotinamide adenine-dinucleotide phosphate (NADP), this energy is then used in photosynthesis of lipids and other essential organic compounds. Also phosphorous is considered as a component of nucleic acids, which necessary for protein synthesis. Similar results observed by Awad et al.; (2009) Abd El-Moneim et al.; (2015) and AboBaker and Hassan (2017). 


\section{Nutrients concentration and uptake}

In general, results in Tables (7) and (8) show that $N$ and $K$ concentration in canola seeds and straw were not affected significantly by applied treatments. The results in the same tables reveal that $P$ concentration and NPK- uptake were significantly increased by the studied treatments. It worthy to mention that the

highest values were obtained under combined treatment of $\mathrm{RP}_{2}+\mathrm{C}_{1}+\mathrm{PDB}_{1}$ followed by treatment of $\mathrm{RP}_{1}+\mathrm{C}_{1}+\mathrm{PDB}_{1}$. Increment values of $\mathrm{RP}_{2}+\mathrm{C}_{1}+\mathrm{PDB}_{1}$ relative to the control were $186.67,63.29$, 352.11 and 69.48 for $P$ content, $\mathrm{N}$-uptake, P-uptake, K-uptake, respectively in seeds whereas, in straw were, 155.56, 56.41, 259.2 and $68.79 \%$, respectively. These increases due to increase in $P$ availability as a result of organic acids produced during organic matter decomposition as well as the chelating effect of organic complexes with $P$. these results are in accordance with those obtained by Abd El-Moneim et al. (2015) and Abo-Baker and Hassan (2017).

Table 6. Seed quality of canola plant as affected by rock phosphate application, compost manure and phosphate dissolving bacteria treatments.

\begin{tabular}{|c|c|c|c|c|c|c|c|c|c|c|}
\hline \multirow{3}{*}{$\mathbf{R P}$} & \multirow{3}{*}{ Compost } & \multicolumn{9}{|c|}{ PDB treatments } \\
\hline & & $\mathrm{PDB}_{0}$ & $\mathrm{PDB}_{1}$ & Mean & $\mathrm{PDB}_{0}$ & $\mathrm{PDB}_{1}$ & Mean & $\mathrm{PDB}_{0}$ & $\mathrm{PDB}_{1}$ & Mean \\
\hline & & \multicolumn{3}{|c|}{ Oil content $\left(\mathrm{g} \mathrm{kg}^{-1}\right)$} & \multicolumn{3}{|c|}{ Oil yield kg ha- ${ }^{-1}$} & \multicolumn{3}{|c|}{ Protein content $\left(\mathrm{g} \mathrm{kg}^{-1}\right)$} \\
\hline \multirow[t]{2}{*}{ RPO } & $\mathrm{C}_{0}$ & 43.82 & 44.00 & 43.91 & 311.86 & 316.45 & 314.16 & 21.18 & 21.25 & 21.22 \\
\hline & $\mathrm{C}_{1}$ & 43.90 & 44.09 & 44.00 & 326.20 & 333.20 & 329.70 & 21.37 & 21.56 & 21.47 \\
\hline \multicolumn{2}{|c|}{ Mean } & 43.86 & 44.05 & 43.95 & 319.03 & 324.83 & 321.93 & 21.28 & 21.41 & 21.34 \\
\hline \multirow[t]{2}{*}{ RP1 } & $\mathrm{C}_{0}$ & 44.23 & 44.29 & 44.26 & 376.60 & 384.80 & 380.70 & 21.43 & 21.50 & 21.47 \\
\hline & $\mathrm{C}_{1}$ & 44.59 & 44.70 & 44.65 & 394.60 & 400.60 & 397.60 & 21.56 & 21.68 & 21.62 \\
\hline \multicolumn{2}{|c|}{ Mean } & 44.41 & 44.50 & 44.45 & 385.60 & 392.70 & 389.15 & 21.50 & 21.59 & 21.54 \\
\hline \multirow[t]{2}{*}{ RP2 } & $\mathrm{C}_{0}$ & 44.91 & 45.08 & 45.00 & 432.50 & 439.54 & 436.02 & 21.62 & 21.75 & 21.69 \\
\hline & $\mathrm{C}_{1}$ & 45.21 & 45.30 & 45.26 & 499.70 & 507.50 & 503.60 & 21.90 & 21.93 & 21.92 \\
\hline \multicolumn{2}{|c|}{ Mean } & 45.06 & 45.19 & 45.13 & 466.10 & 473.52 & 469.81 & 21.76 & 21.84 & 21.80 \\
\hline \multicolumn{2}{|c|}{ Grand mean } & 44.44 & 44.58 & 44.51 & 390.24 & 397.02 & 393.63 & 21.51 & 21.61 & 21.56 \\
\hline \multicolumn{11}{|c|}{ Means of compost } \\
\hline & $\mathrm{C}_{0}$ & 44.32 & 44.46 & 44.39 & 373.65 & 380.26 & 376.96 & 21.41 & 21.50 & 21.46 \\
\hline & $\mathrm{C}_{1}$ & 44.57 & 44.70 & 44.63 & 406.83 & 413.77 & 410.30 & 21.61 & 21.72 & 21.67 \\
\hline
\end{tabular}


Enhancement of rock phosphate applicabilty by compost and

\begin{tabular}{|c|c|c|c|}
\hline $\operatorname{LSD}_{0.05}$ & $\begin{array}{l}\text { RP=n.s C=n.s PDB }=n . s \\
\text { RPXC=0.57 RPXPDB=0.64 } \\
\text { CxPDB=ns RxCXPDB=0.22 }\end{array}$ & $\begin{array}{c}\mathrm{RP}=81.66 \mathrm{C}=29.67 \mathrm{PDB}=4.12 \\
\mathrm{RP} \times \mathrm{C}=89.65 \mathrm{RPxPDB}=89.51 \\
\mathrm{CxPDB}=34.62 \\
\mathrm{RxCXPDB}=79.98\end{array}$ & $\begin{array}{c}\text { RP=ns } C=0.19 \text { PDB }=0.07 \\
\text { RPxC=ns } R P x P D B=n s \\
\text { CxPDB }=0.11 \\
\text { RxCXPDB }=0.35\end{array}$ \\
\hline
\end{tabular}

$\mathrm{RP}_{0}, \mathrm{RP}_{1}$ and $\mathrm{RP}_{2}: 0,250$ and $500 \mathrm{~kg} \mathrm{ha}^{-1}$ of rock phosphate, $\mathrm{C}_{0}$ and $\mathrm{C}_{1}: 0$ and $24 \mathrm{Mg} \mathrm{ha}^{-1}$ of compost $\mathrm{PDB}_{0}$ and $\mathrm{PDB}_{1}$ : none and inoculation with phosphate dissolving bacteria, n.s non-significant at the $5 \%$ levels of probability at L.S.D test.

Table 7. Nitrogen, $P$ and $K$ content and their uptake in seeds of canola plant as affected by rock phosphate application, compost manure and phosphate dissolving bacteria treatments.

\begin{tabular}{|c|c|c|c|c|c|c|c|c|c|c|}
\hline \multirow{3}{*}{$\mathbf{R P}$} & \multirow{3}{*}{ Compost } & \multicolumn{9}{|c|}{ PDB treatments } \\
\hline & & $\mathrm{PDB}_{0}$ & $\mathrm{PDB}_{1}$ & Mean & $\mathrm{PDB}_{0}$ & $\mathrm{PDB}_{1}$ & Mean & $\mathrm{PDB}_{0}$ & $\mathrm{PDB}_{1}$ & Mean \\
\hline & & \multicolumn{3}{|c|}{$\mathbf{N}$} & \multicolumn{3}{|c|}{$\mathbf{P}$} & \multicolumn{3}{|c|}{ K } \\
\hline \multicolumn{11}{|c|}{ concentration $\left(\mathrm{g} \mathrm{kg}^{-1}\right)$} \\
\hline \multirow{2}{*}{ RPO } & $\mathrm{C}_{0}$ & 3.39 & 3.40 & 3.40 & 0.30 & 0.31 & 0.31 & 1.60 & 1.61 & 1.61 \\
\hline & $\mathrm{C}_{1}$ & 3.42 & 3.45 & 3.44 & 0.33 & 0.36 & 0.35 & 1.64 & 1.66 & 1.65 \\
\hline \multicolumn{2}{|c|}{ Mean } & 3.41 & 3.43 & 3.42 & 0.32 & 0.34 & 0.33 & 1.62 & 1.64 & 1.63 \\
\hline \multirow{2}{*}{ RP1 } & $\mathrm{C}_{0}$ & 3.43 & 3.44 & 3.44 & 0.54 & 0.58 & 0.56 & 1.65 & 1.67 & 1.66 \\
\hline & $\mathrm{C}_{1}$ & 3.45 & 3.47 & 3.46 & 0.62 & 0.64 & 0.63 & 1.68 & 1.69 & 1.69 \\
\hline \multicolumn{2}{|c|}{ Mean } & 3.44 & 3.46 & 3.45 & 0.58 & 0.61 & 0.60 & 1.67 & 1.68 & 1.67 \\
\hline \multirow{2}{*}{ RP2 } & $\mathrm{C}_{0}$ & 3.46 & 3.48 & 3.47 & 0.65 & 0.70 & 0.68 & 1.69 & 1.70 & 1.70 \\
\hline & $\mathrm{C}_{1}$ & 3.50 & 3.51 & 3.51 & 0.82 & 0.86 & 0.84 & 1.71 & 1.72 & 1.72 \\
\hline \multicolumn{2}{|c|}{ Mean } & 3.48 & 3.50 & 3.49 & 0.74 & 0.78 & 0.76 & 1.70 & 1.71 & 1.71 \\
\hline \multicolumn{2}{|c|}{ Grand mean } & 3.44 & 3.46 & 3.45 & 0.54 & 0.58 & 0.56 & 1.66 & 1.68 & 1.67 \\
\hline \multicolumn{11}{|c|}{ Means of compost } \\
\hline & $\mathrm{C}_{0}$ & 3.43 & 3.44 & 3.43 & 0.50 & 0.53 & 0.51 & 1.65 & 1.66 & 1.65 \\
\hline & $\mathrm{C}_{1}$ & 3.46 & 3.48 & 3.47 & 0.59 & 0.62 & 0.61 & 1.68 & 1.69 & 1.68 \\
\hline \multicolumn{2}{|c|}{$\operatorname{LSD}_{0.05}$} & \multicolumn{3}{|c|}{$\begin{array}{l}\text { RP=ns } C=0.02 \text { PDB=ns } \\
R P X C=n s \quad R P x P D B=n s \\
\text { CxPDB }=\text { ns RxCXPDB=ns }\end{array}$} & \multicolumn{3}{|c|}{$\begin{array}{c}\mathrm{RP}=0.29 \mathrm{C}=0.07 \mathrm{PDB}=0.01 \\
\mathrm{RPXC}=0.22 \text { RPXPDB }=0.28 \\
\mathrm{CxPDB}=0.09 \\
\mathrm{RxCXPDB}=0.24\end{array}$} & \multicolumn{3}{|c|}{$\begin{array}{l}\text { RP=ns } C=0.02 \text { PDB=ns } \\
\text { RPXC=ns RPxPDB=ns } \\
\text { CxPDB=0.03 RxCXPDB=ns }\end{array}$} \\
\hline \multicolumn{11}{|c|}{ Uptake (kg ha $\left.{ }^{-1}\right)$} \\
\hline \multirow{2}{*}{ RPO } & $\mathrm{C}_{0}$ & 24.08 & 24.45 & 24.27 & 2.13 & 2.23 & 2.18 & 11.37 & 11.58 & 11.47 \\
\hline & $\mathrm{C}_{1}$ & 25.42 & 26.08 & 25.75 & 2.45 & 2.72 & 2.59 & 12.19 & 12.55 & 12.37 \\
\hline \multicolumn{2}{|c|}{ Mean } & 24.75 & 25.26 & 25.01 & 2.29 & 2.48 & 2.38 & 11.78 & 12.06 & 11.92 \\
\hline \multirow{2}{*}{ RP1 } & $\mathrm{C}_{0}$ & 29.20 & 29.89 & 29.55 & 4.60 & 5.04 & 4.82 & 14.05 & 14.51 & 14.28 \\
\hline & $\mathrm{C}_{1}$ & 30.54 & 31.10 & 30.82 & 5.49 & 5.74 & 5.61 & 14.87 & 15.15 & 15.01 \\
\hline \multicolumn{2}{|c|}{ Mean } & 29.87 & 30.50 & 30.18 & 5.04 & 5.39 & 5.22 & 14.46 & 14.83 & 14.64 \\
\hline \multirow{2}{*}{ RP2 } & $\mathrm{C}_{0}$ & 33.33 & 33.93 & 33.63 & 6.26 & 6.83 & 6.54 & 16.28 & 16.58 & 16.43 \\
\hline & $\mathrm{C}_{1}$ & 38.68 & 39.32 & 39.00 & 9.06 & 9.63 & 9.35 & 18.90 & 19.27 & 19.08 \\
\hline \multicolumn{2}{|c|}{ Mean } & 36.01 & 36.63 & 36.32 & 7.66 & 8.23 & 7.95 & 17.59 & 17.92 & 17.76 \\
\hline \multicolumn{2}{|c|}{ Grand mean } & 30.21 & 30.80 & 30.50 & 5.00 & 5.36 & 5.18 & 14.61 & 14.94 & 14.77 \\
\hline \multicolumn{11}{|c|}{ Means of compost } \\
\hline & $\mathrm{C}_{0}$ & 28.87 & 29.42 & 29.15 & 4.33 & 4.70 & 4.51 & 13.90 & 14.22 & 14.06 \\
\hline & $\mathrm{C}_{1}$ & 31.55 & 32.17 & 31.86 & 5.67 & 6.03 & 5.85 & 15.32 & 15.65 & 15.49 \\
\hline
\end{tabular}




$$
\begin{array}{l|c}
L_{S D} & \begin{array}{c}
\mathrm{RP}=5.22 \mathrm{C}=1.79 \mathrm{PDB}=0.39 \\
\mathrm{RPxC}=5.25 \mathrm{RPxPDB}=\mathrm{ns}
\end{array} \\
\text { CxPDB=ns RxCXPDB=ns }
\end{array}
$$

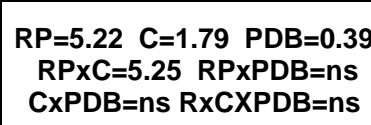

RP=2.66 $C=1.12$ PDB=0.29

$\mathrm{RPxC}=2.33 \mathrm{RPxPDB}=2.55$

$\mathrm{CXPDB}=1.28$

$\mathrm{RXCXPDB}=3.36$
$R P=2.79 \quad C=1.28$ PDB=0.31 RPXC=ns RPXPDB=ns CXPDB=1.37 RxCXPDB=ns

$\mathrm{RP}_{0}, \mathrm{RP}_{1}$ and $\mathrm{RP}_{2}: \mathbf{0}, 250$ and $500 \mathrm{~kg} \mathrm{ha}^{-1}$ of rock phosphate, $\mathrm{C}_{0}$ and $\mathrm{C}_{1}: 0$ and $24 \mathrm{Mg} \mathrm{ha}^{-1}$ of compost $\mathrm{PDB}_{0}$ and $\mathrm{PDB}_{1}$ : none and inoculation with phosphate dissolving bacteria, n.s non-significant at the $5 \%$ levels of probability at L.S.D test.

Table 8. Nitrogen, $P$ and $K$ concentration and uptake in straw of canola plant as affected by rock phosphate application, compost manure and phosphate dissolving bacteria treatments.

\begin{tabular}{|c|c|c|c|c|c|c|c|c|c|c|}
\hline \multirow{3}{*}{$\mathbf{R P}$} & \multirow{3}{*}{ Compost } & \multicolumn{9}{|c|}{ PDB treatments } \\
\hline & & $\mathrm{PDB}_{0}$ & $\mathrm{PDB}_{1}$ & Mean & $\mathrm{PDB}_{0}$ & $\mathrm{PDB}_{1}$ & Mean & $\mathrm{PDB}_{0}$ & $\mathrm{PDB}_{1}$ & Mean \\
\hline & & \multicolumn{3}{|c|}{$\mathbf{N}$} & \multicolumn{3}{|c|}{$\mathbf{P}$} & \multicolumn{3}{|c|}{$\mathbf{K}$} \\
\hline \multicolumn{11}{|c|}{ concentration $\left(\mathrm{g} \mathrm{kg}^{-1}\right)$} \\
\hline \multirow{2}{*}{ RPO } & $\mathrm{C}_{0}$ & 1.27 & 1.29 & 1.28 & 0.09 & 0.11 & 0.10 & 1.06 & 1.07 & 1.07 \\
\hline & $\mathrm{C}_{1}$ & 1.28 & 1.31 & 1.30 & 0.10 & 0.12 & 0.11 & 1.15 & 1.18 & 1.17 \\
\hline \multicolumn{2}{|c|}{ Mean } & 1.28 & 1.30 & 1.29 & 0.10 & 0.12 & 0.11 & 1.11 & 1.13 & 1.12 \\
\hline \multirow{2}{*}{ RP1 } & $\mathrm{C}_{0}$ & 1.31 & 1.32 & 1.32 & 0.12 & 0.15 & 0.14 & 1.18 & 1.20 & 1.19 \\
\hline & $\mathrm{C}_{1}$ & 1.34 & 1.35 & 1.35 & 0.16 & 0.19 & 0.18 & 1.21 & 1.23 & 1.22 \\
\hline \multicolumn{2}{|c|}{ Mean } & 1.33 & 1.34 & 1.33 & 0.14 & 0.17 & 0.16 & 1.20 & 1.22 & 1.21 \\
\hline \multirow{2}{*}{ RP2 } & $\mathrm{C}_{0}$ & 1.37 & 1.40 & 1.39 & 0.16 & 0.19 & 0.18 & 1.24 & 1.25 & 1.25 \\
\hline & $\mathrm{C}_{1}$ & 1.41 & 1.42 & 1.42 & 0.20 & 0.23 & 0.22 & 1.27 & 1.28 & 1.28 \\
\hline \multicolumn{2}{|c|}{ Mean } & 1.39 & 1.41 & 1.40 & 0.18 & 0.21 & 0.20 & 1.26 & 1.27 & 1.26 \\
\hline \multicolumn{2}{|c|}{ Grand mean } & 1.33 & 1.35 & 1.34 & 0.14 & 0.17 & 0.15 & 1.19 & 1.20 & 1.19 \\
\hline \multicolumn{11}{|c|}{ Means of compost } \\
\hline & $\mathrm{C}_{0}$ & 1.32 & 1.34 & 1.33 & 0.12 & 0.15 & 0.14 & 1.16 & 1.17 & 1.17 \\
\hline & $\mathrm{C}_{1}$ & 1.34 & 1.36 & 1.35 & 0.15 & 0.18 & 0.17 & 1.21 & 1.23 & 1.22 \\
\hline \multicolumn{2}{|c|}{$\mathrm{LSD}_{0.05}$} & \multicolumn{3}{|c|}{$\begin{array}{l}\text { RP=ns C=0.02 PDB=ns } \\
\text { RPXC }=0.05 \text { RPxPDB=ns } \\
\text { CxPDB=0.02 RxCXPDB=ns }\end{array}$} & \multicolumn{3}{|c|}{$\begin{array}{c}\text { RP=0.08 C }=0.01 \text { PDB }=0.02 \\
\text { RPXC=ns RPxPDB }=0.03 \\
\text { CxPDB=0.03 RxCXPDB=ns }\end{array}$} & \multicolumn{3}{|c|}{$\begin{array}{l}\text { RP=ns C=0.04 PDB=ns } \\
\text { RPXC=ns RPxPDB=ns } \\
\text { CxPDB=0.03 RxCXPDB=ns }\end{array}$} \\
\hline \multicolumn{11}{|c|}{ Uptake (kg ha-1) } \\
\hline \multirow{2}{*}{ RPO } & $\mathrm{C}_{0}$ & 11.47 & 11.82 & 11.64 & 0.81 & 1.01 & 0.91 & 9.58 & 9.80 & 9.69 \\
\hline & $\mathrm{C}_{1}$ & 11.96 & 12.40 & 12.18 & 0.93 & 1.14 & 1.04 & 10.74 & 11.17 & 10.96 \\
\hline \multicolumn{2}{|c|}{ Mean } & 11.72 & 12.11 & 11.91 & 0.87 & 1.07 & 0.97 & 10.16 & 10.48 & 10.32 \\
\hline \multirow{2}{*}{ RP1 } & $\mathrm{C}_{0}$ & 13.45 & 13.67 & 13.56 & 1.23 & 1.55 & 1.39 & 12.12 & 12.42 & 12.27 \\
\hline & $\mathrm{C}_{1}$ & 14.33 & 14.62 & 14.48 & 1.71 & 2.06 & 1.88 & 12.94 & 13.32 & 13.13 \\
\hline \multicolumn{2}{|c|}{ Mean } & 13.89 & 14.14 & 14.02 & 1.47 & 1.81 & 1.64 & 12.53 & 12.87 & 12.70 \\
\hline \multirow{2}{*}{ RP2 } & $\mathrm{C}_{0}$ & 16.17 & 16.75 & 16.46 & 1.89 & 2.27 & 2.08 & 14.64 & 14.96 & 14.80 \\
\hline & $\mathrm{C}_{1}$ & 17.65 & 17.94 & 17.79 & 2.50 & 2.91 & 2.70 & 15.90 & 16.17 & 16.03 \\
\hline \multicolumn{2}{|c|}{ Mean } & 16.91 & 17.34 & 17.13 & 2.20 & 2.59 & 2.39 & 15.27 & 15.56 & 15.42 \\
\hline \multicolumn{2}{|c|}{ Grand mean } & 14.17 & 14.53 & 14.35 & 1.51 & 1.82 & 1.67 & 12.65 & 12.97 & 12.81 \\
\hline \multicolumn{11}{|c|}{ Means of compost } \\
\hline & $\mathrm{C}_{0}$ & 13.70 & 14.08 & 13.89 & 1.31 & 1.61 & 1.46 & 12.11 & 12.39 & 12.25 \\
\hline
\end{tabular}




\begin{tabular}{|c|c|c|c|c|c|c|c|c|c|}
\hline$C_{1}$ & 14.65 & 14.98 & 14.82 & 1.72 & 2.03 & 1.87 & 13.20 & 13.55 & 13.37 \\
\hline $\mathbf{L S D}_{0.05}$ & $\begin{array}{r}\text { RP=ns } \\
\text { RPxC } \\
\text { CxPDB }\end{array}$ & $\begin{array}{l}=0.77 \mathrm{P} \\
\text { is RPxP } \\
88 \mathrm{RxC}\end{array}$ & $\begin{array}{l}B=0.27 \\
B=n s \\
D D B=n s\end{array}$ & $\begin{array}{r}R P=0.6 \\
R P x C= \\
\text { CxPDE }\end{array}$ & $\begin{array}{l}\mathrm{C}=0.36 \\
11 \mathrm{RPx} \\
\text { is RxC }\end{array}$ & $\begin{array}{l}B=0.22 \\
B=0.88 \\
D B=n s\end{array}$ & $\begin{array}{r}\text { RP=ns } \\
\text { RPxC } \\
\text { CxPDB }\end{array}$ & $\begin{array}{l}\mathrm{C}=1.03 \\
\text { ns RPX } \\
1.06 \mathrm{RxC}\end{array}$ & $\begin{array}{l}\mathrm{B}=0.25 \\
\mathrm{~PB}=\mathrm{ns} \\
\mathrm{PDB}=\mathrm{ns}\end{array}$ \\
\hline
\end{tabular}

$\mathrm{RP}_{0}, \mathrm{RP}_{1}$ and $\mathrm{RP}_{2}: 0,250$ and $500 \mathrm{~kg} \mathrm{ha}^{-1}$ of rock phosphate, $\mathrm{C}_{0}$ and $\mathrm{C}_{1}: 0$ and $24 \mathrm{Mg} \mathrm{ha}^{-1}$ of compost $\mathrm{PDB}_{0}$ and $\mathrm{PDB}_{1}$ : none and inoculation with phosphate dissolving bacteria, n.s nonsignificant at the $5 \%$ levels of probability at L.S.D test.

\section{CONCLUSION}

From these above mentioned results it could be concluded that, the combined use the combination of rock phosphate at rate of $500 \mathrm{~kg} \mathrm{ha}^{-1}$ and compost manure at rate of $24 \mathrm{Mg} \mathrm{ha}^{-1}$ plus seed inoculation with PDB was a good economic return due to the reduction in the mounted mineral fertilizers used and its costs. These results would be an appropriate substitute for chemical phosphorous fertilizer in sustainable agriculture system.

\section{REFERENCES}

A.O.A.C. (1990). Official methods of analysis of the association of official analytical chemists. 12ed Washington.

Abd El-Moneim, I. F., S. A. Moussa and Y. M. El-Edfawy (2015). Effect of rock phosphate along with elemental sulfur, organic manure and biofertilizer on quantitative and qualitative characters of canola (Brassica napus L.) Inter. J. of Acad. Res. 7(2): 149-154.

Abo-Baker, A. A. B. and M. S. Hassan (2017). Evaluation of rock phosphate and potassium feldspar with biological and organic amendments and its effect on soil phosphorus and potassium availability and uptake, growth and yield of canola. Inter. J. of Plant and Soil Sci. 14(5): 1-14.

Ahmed, M. M. M., A. M. Mahmoud and E. B. A. Osman (2005). Recycling of crop residues and using them as a compost to enhance the growth and productivity of canola in newly reclaimed sandy soils. Res. Commune. Of U.S.B. Branch Dobrich, 7: 138-147.
Awad, M. S., A. A. Rashad and M. A. Bayoumi (2009). Effect of farmyard combined with some phosphate sources on the productivity of canola plants on a sandy soil. J. of Agric. and Bio. Sci. 5(6): 1176-1181.

Chapman, H. D. and R. F. Pratt (1961). Methods Analysis for Soil, Plant and Water. Div. Agric. Sci., Univ. of California, USA, pp. 16-38.

Deyoe, C. W. and Shellenberger (1965). Amino acids and proteins in sorghum grain. J. Agric. and Food Chem., 13:446-452.

El-Edfawy, Y. M. (2012). Integrated effect of bio, inorganic and arganic fertilizer on canola production. Ph., Thesis, Fac. of Agric. Banha University.

Gyaneshwar, P., N. Kumar, L. J. Parekh and P. S. Poole (2002). Role of soil microorganisms in improving $P$ nutrition of plants. Plant Soil 245: 8393.

Issam, I. B. and A. H. Sayegh (2007). Methods of Analysis for Soil of Arid and Semi-arid Regions. FAO. Rome, Italy.

Jackson, M. L. (1973). Soil Chemical Analysis Prentice- Hall, Englewood Cliffs, New Jersey, USA.

Khan, A. A., G. Jilani, M. S. Akhtar, S. M. S. Naqvi and M. Rasheed (2009). Phosphorus solubilizing bacteria: occurrence, mechanism and their role in crop production. J. Agric. Biol. Sci. 1: 48-58.

Klute, A. (1986). Methods of analysis. Part - 1 physical and mineralogical methods $\left(2^{\text {nd }}\right.$ ed.) Amer. Soc. Of Agron. Madison, Wisconsin, USA.

Leilah, A. A. and S. A. Al-Khateeb (2003). Growth and yield of canola (Brassica 
napus L.) in relation to irrigation treatments and nitrogen levels. J. Agric. Sci. Mansoura Univ., 28: (2) 819828.

Makovacki, N. and V. Milic (2001). Use Azotobacter chroococcum as potentially useful in agricultural application. Ann. Microbiology, 51:145-158.

Romano, S., V. Bondarev, M. Kölling, T. Dittmar and H. N. Schulz-Vogt (2017). Phosphate limitation triggers the dissolution of precipitated iron by the marine bacterium Pseudovibrio sp. FO-BEG1. Frontiers in Microbiology. 8(125):155-166.

Sendecor, G. and W. G. Cochron (1980). Statistical methods, $7^{\text {th }}$ Ed; I Owa Stute Univ. Press, low, U.S.A.

Thirumaran, G., M. Arumugam, R. Arumugam and P. Anantharaman (2009). Effect of seaweed liquid fertilizer on growth and pigment concentration of Cyamopsis tetrogonolaba (L) Taub. AmericanEurasian J. of Agron., 2 (2): 50-56.

Vassilev, N., M. Vassileya and I. Nikolaeva (2006). Simultaneous $P$ solubilizing and biocontrol activity of microorganisms: potentials and future trends. Appl. Microbiol. Biotechnol. 71: 137-144.
Watanabe, F. S. and S. R. Olsen (1965). Test of ascorbic and method for determining phosphorous in water and $\mathrm{NaHCO}_{3}$ extract from soil. Soil Sci Cos. Am. Proc., 29: 677-683.

Yadav, H., R. K. Gothwal, M. Sujata and P. Ghosh (2014). Bioactivation of Jhamarkotra rock phosphate by a thermotolerant phosphate-solubilizing bacterium Bacillus sp. BISR-HY63 isolated from phosphate mines. Arch. Agro. Soil Sci. 61: 1125- 1135.

Yang, S. S. (2003). Application of microbial fertilizers on the three objectives agriculture. In: Chou, C.H., Yang, S.S. (Eds.), Challenge of Three Objectives in Agriculture. Council of Agriculture, Southern Taiwan Joint Services Center of Executive Yuan, Institute of Biotechnology of National Pingtung University of Science and Technology, Department of Biochemical Science and Technology of National Taiwan University, Taiwan, pp. 265-292.

Zapta, F. and R. N. Roy (2004). (U R S A) use of rock phosphate for sustainable agriculture. Food agriculture organization and water development division, Oleo Rome. 
زيادة فاعلية صخر الفوسفات بواسطة الكمبوست والبكتريا المذيبة للفوسفات وتأثيرها على جودة وإنتاجية نبات الكانولا النامى فى أرض رملية

$$
\text { ياسر محمد الإدفاوى ، محيى محب هرفى }
$$

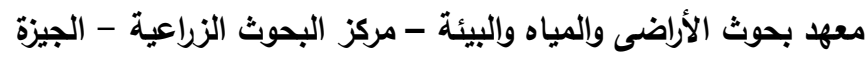

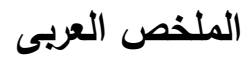

أقيمت تجريتان حقليتان فى الموسمين الشتويين 2015/2014 و 2015 / 2016 بمحطة بحوث الإسماعيلية التابعة لمركز البحوث الزراعية محافظة الإسماعيلية - مصر ـ تهلف الارلسة لتقييم زيادة فاعلية صخر الفوسفات بإضافة

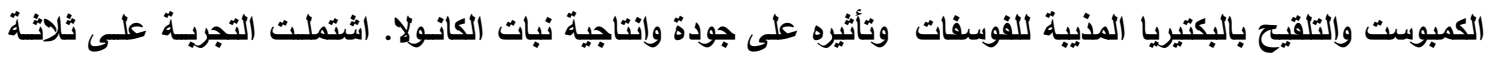

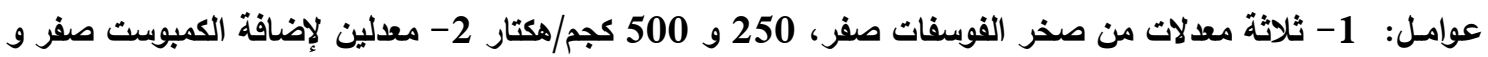

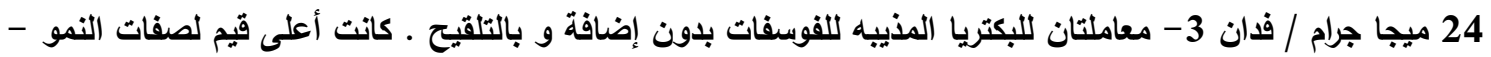
المحصول - مكونات المحصول - جودة البذور - محتوى النبات والممتص من الغناصر الغذائية لنبات الكانولا وجلت فى المعاملة معدل 500 كجم /هكتارمن صخر الفوسفات + إضافة الكمبوست + التلقيح بالبكتريا المذيبة للفوسفات . ويمكن التوصية بأن إضافة صخر الفوسفات بمعل 500 كجم / هكتار مع إضافة الكمبوست بمعدل 24 ميجا جرام /

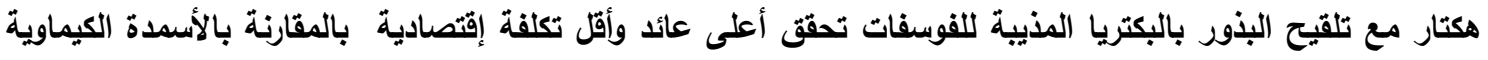
ويمكن أن تحل محل الأسمدة الفوسفاتية الكيميائية لنظام الزراعة المستدامة. 
أسماء السادة المحكمين

$$
\text { أ أ.د/ محمد عبدالغنـى حســـن معهل بحوث الأراضى والمياه والبيئة - الجيزة }
$$

